\title{
Regional Environmental Change \\ Assessing the Success of Integrated Shoreline Management in the Tordera Delta, Northeastern Spain \\ --Manuscript Draft--
}

\begin{tabular}{|c|c|c|}
\hline Manuscript Number: & \multicolumn{2}{|l|}{ REEC-D-18-00649R4 } \\
\hline Keywords: & \multicolumn{2}{|c|}{$\begin{array}{l}\text { beach erosion; Artificial nourishment; Seasonality; Ecosystem-based management; } \\
\text { Beach functionality }\end{array}$} \\
\hline \multicolumn{3}{|l|}{$\begin{array}{l}\text { Corresponding Author Secondary } \\
\text { Information: }\end{array}$} \\
\hline First Author: & \multicolumn{2}{|l|}{ Enric Sagristà, Ph.D. student } \\
\hline \multicolumn{3}{|l|}{ First Author Secondary Information: } \\
\hline \multirow[t]{2}{*}{ Order of Authors: } & \multicolumn{2}{|l|}{ Enric Sagristà, Ph.D. student } \\
\hline & \multicolumn{2}{|l|}{ Rafael Sardá } \\
\hline \multicolumn{3}{|l|}{ Order of Authors Secondary Information: } \\
\hline Funding Information: & $\begin{array}{l}\text { Plan Nacional de I+D+i de España } \\
\text { (CGL2013-49061) }\end{array}$ & Dr. Rafael Sardá \\
\hline \multicolumn{3}{|l|}{ Additional Information: } \\
\hline Question & \multicolumn{2}{|l|}{ Response } \\
\hline $\begin{array}{l}\text { Has your submission been invited to a } \\
\text { special issue currently in preparation for } \\
\text { this journal? }\end{array}$ & \multicolumn{2}{|l|}{ No } \\
\hline $\begin{array}{l}\text { If yes, please ensure that your submission } \\
\text { occurs according to the approved plans of }\end{array}$ & & \\
\hline
\end{tabular}


the respective guest editors. If this is the case, please give the title of the Special Issue and the name of the editors you have been in contact with here.

\section{Author Comments:}

Dear Mr. Cramer

We uploaded our revised version of the paper into the platform. We really appreciated the tremendous effort made by the reviewer in polishing the English style of the manuscript. We recognize right now that the reading of the manuscript is much better. All the comments from the reviewer and yours are addressed in the letter of reply. Hope this can finish the process for the manuscript.

Best wishes.

Enric and Rafael 
1 Assessing the Success of Integrated Shoreline Management in the Tordera Delta, Northeastern

3 4

\title{
Spain
}

\author{
Authors: \\ Enric Sagristà (CEAB-CSIC ${ }^{1}$ ) e.sagrista@ceab.csic.es \\ Rafael Sardá (CEAB-CSIC ${ }^{1}$ ) sarda@ceab.csic.es \\ ${ }^{1}$ Centro de Estudios Avanzados de Blanes (CEAB-CSIC).

\section{Corresponding author:} \\ Name: Enric Sagristà \\ Professional affiliation: Centro de Estudios Avanzados de Blanes (CEAB-CSIC) \\ Professional address: Carretera d'Accés a la Cala St. Francesc, 14, 17300 Blanes (Girona, Spain) \\ E-mail address: e.sagrista@ceab.csic.es \\ Telephone number: (0034) 630675704
}

\section{ABSTRACT}

Coastal catchment zones have undergone enormous changes during recent decades that have compromised their resilience. As a consequence of largely fragmented coastal management frameworks in the delta region of the Tordera River, the beach of S'Abanell, located on the northern arm of the delta, was in a critically degraded condition by the end of 2006. To remedy this situation, the beach was artificially nourished with sand during the period 2007-2009. After nourishment, we observed a general trend of recovery of the width of the beach, in its northern and central parts, and the reappearance of a pattern of seasonal oscillation. This tendency was not observed in its southern part, near the river mouth, where the situation is still critical today. Tracing decadal evolution of the problem, we strengthen the knowledge base by compiling a history of past human decisions responsible for the present situation. We promoted stakeholder engagement and participation aimed at reducing human pressures affecting the evolution of the beach and the loss of ecosystem services. The overall idea was to take the initial steps needed to shift the management of this coastal region towards ecosystem-based management principles. This research demonstrates that, under certain conditions, artificial nourishment can contribute to restore beach health on a decadal scale.

Key words: Beach erosion; Artificial nourishment; Seasonality; Ecosystem-based management; Beach functionality

\section{Length of the manuscript:}

Number of words: 5,614

Number of figures: 6 (1,800 words)

Total length (including figures and tables count): 7,414 
Marine deltas are retreating around the world (Valiela, 2006). They have undergone enormous changes during recent decades, suffering pervasive coastal degradation due to human-related alteration of sediment transportation and other global processes (Ericson et al., 2006; Nicholls et al., 2007; UNESCOIRTCES, 2011). In addition, delta areas are social-ecological systems where land-sea interactions become of great importance and where we observe frequent management problems associated with the absence of coordinating mechanisms that can solve the issue of different government agencies under significant overlapping jurisdictions managing the same environment. Policy fragmentation is an impediment to the sustainable development of coastal resources (Cormier et al., 2010).

Along the north-eastern sedimentary coast of Spain, erosion is the dominant process; beaches are being eroded at an average rate of about $1 \mathrm{~m}$ per year (CIIRC, 2010; Jimenez et al., 2016). Present sea-level trends in the Mediterranean basin have been estimated by Marcos and Tsimplis (2008) by analyzing available tide-gauge records longer than 35 years between 1.2 and $1.5 \mathrm{~mm}$ yr-1; the same authors estimated in $1.7 \mathrm{~mm}$ yr-1 a sea-level 13-year long time series in the Barcelona Harbor. Based on these estimates, we can assume that the average rate sea level rise in the region is around $1.5 \mathrm{~mm}$ per year, corresponding to a retreat of approximately $15-20 \mathrm{~cm}$ of the beach strands along the coast (Schwartz's Bruun rule; Schwartz, 1967). The remaining $80 \mathrm{~cm}$ per year can be explained, in part or perhaps completely, by human interference with natural depositional processes due to changes in runoff and sediment delivery to the coast.

By the end of 2006, following an erosive period that spanned three decades, many stretches of S'Abanell Beach (a popular beach located on the northern arm of the Tordera Delta) had disappeared (Sagristà et al., 2019; Sardá et al., in press). Consequently, the attraction of the beach for the public was reduced and inland exposure to coastal storms increased. Due to the importance of this beach for the economy of the region, different stakeholders at the local (delta municipalities), regional (Catalan authorities) and national (Spanish authorities) level started to analyse what could be done to alleviate the erosion problem and to restore this particular environment. Not a single solution for $\mathrm{S}^{\prime}$ Abanell Beach was seen as plausible and the implementation of various partial solutions, which corresponded to several reactive measures (to mitigate or reduce the problem instead of prevent it) was deemed necessary.

Artificial beach nourishment with sand is a common practice to combat coastal erosion problems (Speybroeck et al., 2006). In 2007, as a response to different stakeholder demands, we were asked to advise on short- to long-term measures needed to deal with the critical condition of S'Abanell beach (Jimenez et al., 2007). Our report concluded that immediate nourishment actions were necessary to address the problem of beach erosion and that an integrated land-use plan for the delta region was needed to restore ecosystem functionality that supported habitat conditions and water and sediment processes. Along with this previous idea, a campaign was initiated to gain understanding of the main causes of the coastal erosion problem and to educate the public and competent authorities.

The geomorphological evolution of the Tordera Delta over a 50-year period was assessed, correlating observed changes with human actions, such as land-use transformations and other actions that interference with natural process (Sagristà et al., 2019; Sardá et al., in press). The assessment facilitated decision making leading to a decrease in harmful human-mediated activities such as submarine dredging of sediment, sediment extraction from the river, beach occupation or coastal squeeze activities that had been placing coastal systems under pressure and demanded the implementation of further corrective measures.

In this paper, we report the initiatives carried out to deal with the problem of the disappearance of S'Abanell Beach at the end of 2006, after a long period of erosion (Sagristà et al., 2019; Sardá et al., in 
press). A decadal analysis of the effects of nourishment actions on beach condition is presented. The main goal of this work was to evaluate the effectiveness of the measures implemented in the S'Abanell Beach area to mitigate the erosion process and restore the beach. In addition, we discuss the initiatives carried out to reverse the causes of beach erosion by promoting an ecosystem-based framework for moreintegrated management of the coastal region in the future.

\section{MATERIALS AND METHODS}

\section{1) Study area and nourishment activities} S'Abanell Beach

97 S'Abanell Beach is located on the northern arm of the Tordera Delta (Figure 1). The delta (12 $\left.\mathrm{km}^{2}\right)$ 98 constitutes the alluvial plain of the Tordera River watershed $\left(894 \mathrm{~km}^{2}\right)$. The Tordera River is one of the most important streams in Catalonia. Its watershed receives an average annual rainfall between 400 and $600 \mathrm{~mm}$ per year (Rovira et al., 2005). S'Abanell is a typical Mediterranean beach suffering coastal squeeze due to the historical destruction and further occupation of the dune systems and other vegetated areas (Pintó et al., 2014; El Mrini et al., 2012). This fact has led to the partial integration of the beach into an urban environment that has reduced its capacity to absorb eroding forces. The northern and central stretches of the beach ( $1.7 \mathrm{~km}$; colored orange in Figure 1) are located in an urban environment having a seafront promenade right next to the beach. The southern stretch is in a suburban area where many campsites are established and no promenade was developed $(0.6 \mathrm{~km}$; colored green in Figure 1). The beach is highly occupied by people during the bathing season and cleaning activities are carried out in order to satisfy the social requirements of tourist amenities (Suarez de Vivero and Rodriguez Mateos, 2005; Serra and Pintó, 2005; Ariza et al., 2007; 2008a, 2008b). A historical geomorphological study of this beach (Sagristà et al., 2019) showed that in the period 1956-2006 the entire northern arm of the beach and the surroundings of the mouth of the river were eroded; while the southern arm of the delta experienced net accretion (colored blue in Figure 1). Figure 1 also shows an overall loss of beach area in the delta region from 1956 to 2006 (shoreline colored red) as well as the increase in beach area on the southern arm of the delta (shoreline colored blue).

\section{$<$ FIGURE 1>}

S'Abanell Beach is maintained by sediments that come from the fluvial course of the Tordera River (Vila and Serra, 2015). The river follows a Mediterranean flow regime characterized by having a high seasonal component, with a wide range of flows of torrential character due to its rapid response to rainy episodes that can end in floods alternating with large dry periods (Rovira et al., 2004). However, during the last sixty years, the downstream part of the Tordera watershed and the delta region has undergone many changes in flow dynamics, lamination conditions, land use and water usages, reducing its water and sediment flow to the sea (Sagristà et al., 2019).

A large delta aquifer occupies the region, but its groundwater is withdrawn and overexploited. Every year, large water extraction activities can be measured mostly during the bathing system due to tourism and recreational activities and, as a consequence, the aquifer level is abruptly diminished as groundwater depletion exceeds the rate of recharge. The aquifer does not become saltier, however, the subsequent sources of recharge, rainwater in late summer and fall, mostly serve just to recharge it. In a normal year with normal raining conditions, during summer and fall months, the Tordera Delta is characterized by the absence of a water regime flow, beyond the underground regime of its aquifer. During these months, the mouth of the river is closed and neither water nor sediment flows into the sea. However, occasionally, heavy rainfall in the watershed can cause large discharges of water and as a result, the sand bar at the mouth breaches. As a consequence of these conditions, the beach has experienced powerful erosion processes leading to the complete disappearance of some stretches (Sagristà et al., 2019). By the end of 
2006 the beach had almost completely lost its protective services, such as storm surge protection, and many small public interventions were performed to mitigate consequent problems.

\section{Beach nourishment activities}

The first desalination plant of Catalonia was built at the end of last century in the Tordera Delta and initiated its activities in 2001. The plant was built on the river side, $500 \mathrm{~m}$ from the mouth of the river and required nine wells for pumping sea-water and a power generation house. This infrastructure is located inside expropriated areas formerly used as camping sites. When these facilities were constructed in the year 2000, they were at a distance of $40 \mathrm{~m}$ from the shoreline. Within a few years, accelerated erosion of the shoreline exposed the wellheads and powerhouse to direct contact with the sea. In November 2007, the Catalan Water Agency carried out a nourishment project at the southern part of S'Abanell Beach $\left(180,000 \mathrm{~m}^{3}\right)$, an intervention considered of urgency to protect those infrastructures (nine pumping wells and a power generation house). This first nourishment project ended in complete failure due to several December storms that eroded the nourished sand within a month (Sagristà et al., 2019; Sardá et al., in press). Following this episode, the wells and the power house were disconnected and dismantled in 2014 and another system of seawater extraction was installed for the desalination plant. Following the first project, two other nourishment projects were carried out by the Spanish Ministry of Environment, Rural and Marine Affairs. In April 2008, 150,000 $\mathrm{m}^{3}$ of sand were deposited to the central part of the beach and, in August 2009, another 250,000 $\mathrm{m}^{3}$ were deposited on its northern part.

\section{2) S'Abanell Beach evolution}

\section{Beach width (BW)} elevated coastal point in the "Muntanya de Sant Joan" (Figure 2A). This point of observation is located at $180 \mathrm{~m}$ above sea level and $1 \mathrm{~km}$ from the northernmost end of the beach. Photographs are taken with a reflex camera and always from exactly the same geographical point with the same angle and zoom. We have weekly data from 2010 to August 2018 and less frequently (but at least monthly) the first year of record (2009). The photographs were used to measure beach width. Measurements relied on in this work were taken only from photographs in which the shoreline was clearly defined. The rest of the images, where incidental waves did not allow us to trace the coastline accurately, were discarded from the analysis.

Beach width measurements were initially obtained in six transects (Figure 2B) spatially distributed across the beach. Photographs were analysed using photo processing software (Image ${ }^{\circledR}$ ) on a weekly basis. Visual references were used to adjust the measurements taken. A ground truthing analysis of the photographic records was carried out by calibrating "in situ" measurements and photo processing results; a possible error in the recorded data between 1 and $3 \mathrm{~m}$ was detected. All pictures and measures have been analysed by the same person to minimise further cumulative errors.

$<$ FIGURE-2>

Beach width (BW) is normally considered a key indicator in beach management processes (Sardá et al., 2015). Moreover, BW is used in the Beach Quality Index (Ariza et al., 2010), a composite index (BQI) developed to measure the three main ecological functions of a beach (recreational, natural and protective). The BQI can be used as a balance tallying tool for modern beach management processes (Sardá et al., 2015). To further assist management schemes, we designed a graphic display aiming for a better visual interpretation of BW measures. Previous studies carried out on this beach have shown that $26 \mathrm{~m}$ is the minimum width necessary for S'Abanell to protect facilities in the rear front of the beach (see IPP section below; Valdemoro and Jimenez, 2006; Ariza et al., 2010). The measurement taken from the photographs was placed on top of a four-coloured layer that qualifies the protective function of the beach: 
181 a) blue; good status, width greater than $30 \mathrm{~m}$; b) orange; pre-alert status, between 26 and $30 \mathrm{~m}$; c) red; 182 alert status, between 10 and $26 \mathrm{~m}$ and; d) black; critical status, less than $10 \mathrm{~m}$ width.

206

Transect 6 was placed at the southernmost part of S'Abanell Beach. High rates of shoreline retreat experienced at the river mouth caused transect 6 to be disconnected from the coast, reaching 0 metres in width by 2012. A new methodology was then developed to study the coastal evolution of the beach in this particular area (Figure $2 \mathrm{C}$ ). The new methodology has many commonalities with the previous one regarding data collection and processing (a set of photographs, the software used for the analysis, clear shoreline differentiation and consistent personnel involvement). The difference was related to its measured parameter. An indirect measure of surface area was developed to represent the surface of the beach area that appeared in the photographs between a well-established line and the beach/sea water interface (Figure 2C). This new measurement did not give a precise area, rather it was used as a comparative measure between photographs to analyse erosion trends. We also measured the distance between the end of the powerhouse and the shoreline as distance $\mathrm{A}$ in Fig. $2 \mathrm{C}$. We set the scale giving a value of 1 to the length of the water powerhouse directly shown in these pictures (Ref in Figure 2C).

\section{Partial Protection Index (IPP)}

The partial protection index (IPP) is a sub-index used in the BQI (Ariza et al., 2010). The IPP measures beach capacity to dissipate wave energy and to prevent structural damage to promenades and maritime facilities. The IPP is comprised of three different sub-measures: (i) the effective beach width (EBW), which is the distance between existing infrastructures and the shoreline; (ii) the storm reach (SR), which is the beach width potentially eroded by a storm of a given return period; and (iii) the minimum beach width (MBW), which is the minimum width of operative beach required for protection purposes (i.e. for beach infrastructures to be protected from storm impacts). This index must be defined by managers and based on scientific knowledge. In our study, the SR was estimated for the study area as $13 \mathrm{~m}$ (for the effect of a storm with a return period of 10 years, and using the Sbeach model (Larson and Krauss 1989) and the MBW was set at $13 \mathrm{~m}$. Then, the IPP is measured using the following formula:

$$
I P P=\frac{L(I P P 1>1)}{\text { Ltotal }}
$$

Where,

$$
I P P 1=\frac{E B W}{S R}+M B W
$$

Where IPP1 is the partial protection index for a particular point of the beach, and IPP is the partial protection index for the whole beach. The IPP measures the percentage (from 0: no protection to 1: full protection) of the beach with the length of IPP1>1 in relation to the total length of the beach (Ltotal). Previous calculations have shown that the protective function of S'Abanell will become less effective if the width of the beach decreases to less than $26 \mathrm{~m}$ (Ariza et al., 2010).

\section{Rainfall, swell and beach dynamics}

Daily total rainfall was obtained from the meteorological station of Malgrat de Mar (Meteorological Service of Catalonia-Meteocat - XEMA). The station of Malgrat de Mar was the only meteorological station of the Tordera River basin that has a series of data long enough to evaluate variations in the pluviometry regime over the last sixty years. We used these data as an indirect measure of precipitation for the entire basin. Due to the relatively small size of the Tordera basin, there were no significant differences between average pluviometry at different sites of the whole basin.

Swell dynamics (wave height and direction) data were obtained from the SIMAR network (point 2118140) of the Spanish Agency "Puertos del Estado" (Puertos del Estado, 2016). Data were obtained from a 
numerical prediction model, WAM model (TW Group, 1988), with a temporal cadence of 1 hour based on REDEXT buoy network, REDMAR tide gauge network and directional wind data (Puertos del Estado, 2016). These types of data are suitable for calculating swell regimes (de Farias et al., 2012). The time series of significant wave height and predominant wave direction have been obtained from these data and compiled in a Microsoft Excel database.

Beach dynamics (erosion/accretion processes) in relation to river floods, sand bar breaching, and swell dynamics, were studied in detail from November 2015 to December 2016 (Figure 6). Data obtained were represented in a graphic design display that could also be used for further management processes. In the graphic design display for managers, the width of the first five transects was correlated with river floods at the deltaic plain (Type 1-C1 flow $>20 \mathrm{~m}^{3} / \mathrm{s}$; Type 2-C2 between 20 and $5 \mathrm{~m}^{3} / \mathrm{s}$ flow and; Type 3-C3 flow $<5 \mathrm{~m}^{3} / \mathrm{s}$ ) and the sand bar breaching in the river mouth (coloured green: Figure 6, bottom graph)). The beach evolution was represented by shades of blue; dark for accretion or light for erosion (Figure 6, middle graph). At each transect, swell dynamics were represented using brown for easterly swell and grey for south-westerly swell (Figure 6, upper graph). We monitored breaches of the sand bar in the mouth of the Tordera River from a visual observation of weekly photographs; this is a very simple series in a database with bimodal (yes or no) data.

\section{3) Societal engagement}

243 Over the past two decades, natural resource managers and other stakeholders in the Tordera Delta region have become increasingly concerned about the trends and impacts of erosion along S'Abanell Beach. We have recommended a move towards a more integrated, ecosystem-based approach for beach management that focuses on restoring deltaic processes, understanding the influence of seasonal maritime conditions and aquifer recharge, and actions that enhance sediment delivery and retention along the coastline. To move in this direction, two activities were initiated. To facilitate societal participation (active involvement of those people influencing and affected by management actions), an element required for ecosystem-based management, we initiated a consultation process. We favoured an initial dialogue with stakeholders in the four municipalities of the delta region with the aim of developing an effective governance structure according to an ecosystem-based management system (Sardá et al., 2014). To deepen understanding of the causes that have led to the deltaic retreat and as a mandate of the governance structure created, an environmental overview and assessment report for the delta region was carried out as a preliminary diagnosis to strengthen the knowledge base of the problem of coastal erosion in the area.

\section{RESULTS}

\section{1) S'Abanell Beach evolution (2009-2018)}

During the last decade, the two stretches of S'Abanell Beach examined have evolved differently. While the northern and central parts (almost 75\% of the beach; T1-T2 for the northern part and T3-T4 for the central part) showed accretion, the area of the beach near the river mouth continued to erode. The weekly evolution of the five transects in the northern-central part of the beach is presented in Figure 3 . The sporadic large width values over the year mean observed in 2009 (transects 1 to 3) correspond to the last artificial nourishment carried out on the beach. Following a period of stability after nourishment, an improvement became evident in these five transects. Improvement was seen earliest in the northernmost transects analysed, moving south during successive years. In addition, from 2011, initially in transects 1 to $3, S^{\prime}$ Abanell Beach started to recover some seasonal variation. Beach width was clearly larger in spring and summer and reduced during autumn, recovering again during the next seasonal cycle. 
On the contrary, the southernmost part of S'Abanell Beach experienced erosion. From 2009 to 2016, the indirect measurement taken from the photographs (surface area) was reduced by $36.6 \%$ (Figure 4). Besides a period of time (Dec 2015/Feb 2016) when the beach experienced a large increase in the beach area due to an important river flood episode, the rest of the sampled time just losses of sand were observed. Main losses in this area were produced during 2009-2010 and during 2015-2016, The period from 2011 to 2014, characterized as a long drought episode with calm swell dynamics, yielded a period of stability for the beach. In contrast to the northernmost beaches, seasonal dynamics were not observed in this area.

\section{<FIGURE-4>}

The evolution of the IPP index for the six analysed transects is shown in Figure 5. Except for the former sixth transect allocated in its southernmost past, all the other transects showed a progressive improvement in the IPP that matches the accretion process shown on these stretches of the beach. Transect 6 reached $0 \mathrm{~m}$ in 2012 and since then the reference points have been under the sea. The upper graph of Figure 5 shows the recovery of beach width, as indicated by the IPP. The lower graph of Figure 5 indicates the global value of the IPP index for the entire beach (black) and for the northern-central parts (transects 1 to 5; white). At the end of 2017, all northern and central parts of the beach had a width larger than $26 \mathrm{~m}$, making it capable of carrying out its protective function against rough conditions in this part of the Mediterranean Sea.

\section{$<$ FIGURE-5>}

River floods and coastal swell dynamics are the two major forces determining erosion/accretion processes (Valiela, 2006). A few months after the last of the three beach nourishment projects the area endured one of the hardest autumn/winter seasons of the studied decade (Durán et al., 2016). Several sea storms with waves that exceeded $4 \mathrm{~m}$ (at point 2118140 of the SIMAR network) hit S'Abanell and exacerbated the shoreline erosion. In addition, despite significant rainfall, sedimentary river inputs went to the south, due to the predominantly easterly swell. During the following two years (2011-2012), a rebalancing process was observed, with the beach displaying a plateau morphology for all transects (Figure 3 ). A period of intense rainfall in the autumn of 2011 (up to $130 \mathrm{~mm}$ per day), combined with moderate easterly storms alternating with south-easterly swell, seemed to be the perfect conditions to feed the beach. However, this post-summer rain episode with a very low aquifer level in the Tordera Delta served mostly to feed the aquifer, with few sedimentary inputs reaching the sea. For these reasons, only transects 4 and 5 of S'Abanell experienced an increase in beach width, while in the central and northern areas (T1, T2 and T3) the plateau morphology continued, with evidence of seasonality occurring in the northernmost part. The next two years (2013-2014) saw a severe drought episode with exceptionally calm swell dynamics. The frequency, intensity, duration, and erosion forces of easterly storms was reduced during this time. Sedimentary inputs of the Tordera River also decreased due to scarce rainfall of only 300-400 mm per year, but a general increase in beach width was observed along with some episodes of seasonality, which means that in some years we can observe seasonality while others do not, mostly in the northern part. Despite small episodes of easterly stormy weather conditions, the increase of beach width has continued through 2018. January 2017 saw a second period of very rough sea conditions and stormy weather. In contrast to the beginning of the studied period, after a few months, these conditions served to enlarge beach width especially in the central part.

Beach dynamics were analysed in more detail from November 2015 to December 2016 (Figure 6). Accretion in the littoral zone was mostly related to sand bar breaching in the mouth of the river and its consequent water discharges. The Tordera Delta aquifer was, and is, heavily exploited, especially during 
the summer season because of the seasonal increase in population (Sardá \& Fluvià, 1999). Due to the large amount of fresh-water extracted from wells across the deltaic plain, river floods could not be completely correlated with rainfall data in the watershed. From June to November, most of the rainwater channeled by the river did not reach the sea because it was diverted, when crossing the deltaic plain, into the delta aquifer. Figure 6 shows the effects of these two different episodes on S'Abanell Beach, both for the northern transects ( 1 to 3 ) and the central transects ( 4 and 5) of the beach. In October 2015, prior to the dynamics shown in Figure 6, a large C1 flood took place and all transects showed immediate accretion, which means the day after the start of the flood episode (Figure 3). In spite of not having another episode of $\mathrm{C} 1$ flood during the studied period, our analysis served to see that for C2 and C3 floods the beach response is more delayed. Sediments entering into the area as a consequence of C1 (October 2016) and C2-C3 (Winter 2016) floods travel south to north, to be deposited on the beach and mobilised in spring and summer by a general pattern of south-westerly swell. When the mouth of the river is closed, erosion processes usually follow easterly swell conditions while the south-westerly swell produces accretion patterns in the three first transects and erosion in the other two. Obviously, this claim seems to be more supported during the fall months (October-December) when maritime storm intensity and frequency are greatest. During summer months, we can find some accretion periods during easterly swell due to their low intensity and duration that prevents erosion and because usually they are followed by south-westerly swells that generate accretion.

\section{$<$ FIGURE-6>}

\section{2) Towards an effective governance structure}

To ensure further improvements in beach width, a consultation process involving successive contact with the different administrative offices responsible for S'Abanell Beach, was carried out. The complexity of the project was amplified by necessary interactions with associated land-based offices, located in the Tordera catchment area, whose responsibilities and policy objectives were not directly related to beach functional integrity. Following these consultations, in June 2017, a proposal for the creation of a Tordera working group ("Taula de la Tordera") was approved by the four municipalities of the delta region as a governance structure to deal with the problem of delta erosion and river functionality. The main objective of the Tordera working group was to redress the present situation by recovering the social-ecological functionality of the delta region and reducing its vulnerability by developing in the near-future an integrated management plan for the delta region. As a first mandate from this governance structure, an overview and assessment report was requested: a preliminary diagnosis upon which they could base future actions, ensuring proactive, planned responses to delta functionality and coastal erosion.

The overview and assessment report was presented in June 2018 in front of the Tordera working group (Taula de la Tordera). The assessment identified essential processes that determine the resilience of the delta and the provision of its most important ecological services. Two of these essential processes, sediment transport to the coast and aquifer recharge, were considered critical factors to consider in mitigating erosion along the delta beaches, including S'Abanell. The assessment concluded with the need of future integrated work to recover an ecological flow of the river to redress these essential processes.

\section{DISCUSSION}

Deltas are widely recognised as being highly vulnerable to natural forces and subject to stressful pressures imposed by human interventions (Valiela, 2006; Ericson et al., 2006; Nicholls et al., 2007; UNESCO-IRTCES, 2011). The Tordera Delta and its northern arm, the beach of S'Abanell, have not escaped this global trend. During recent decades, S'Abanell Beach has suffered from a reduction in its sediment supply (Sagristà et al., 2019; Sardá et al., in press). As a result of multiple factors, infrastructure located along the landward edge of the beach was being increasingly exposed to damage during storm events. During 2006-2007, the 
beach was in a critical condition, having lost its entire width at some stretches. To combat erosion, artificial sand nourishment practices and a proactive governance initiative were activated.

By August 2018, the northern and central parts of S'Abanell Beach had increased their width to over 26 $\mathrm{m}$ : the width required for the beach to exercise its protective function against a 10 -year return period storm (Ariza et al., 2010), according to the SBEACH model (Larson and Kraus, 1989). After a period of beach profile stabilisation that followed a nourishment project in 2009, from 2012-2018 we have seen a trend towards recovery of the northern and central parts of the beach. This positive trend was enhanced by the fact that during the years of this study (2007-2018) the region did not undergo extreme storm events that could have adversely affected the recovery process (Durán et al., 2016; Mendoza and Jiménez, 2008). However, at the southernmost part of S'Abanell, near the mouth of the river, we saw the opposite trend; the beach continued to suffer extensive retreat, with jetties appearing to amplify erosion due to their design or location. Further measures, such as reducing groundwater extractions or restoration projects in wetland morphology, to alleviate pressures in this area (Sagristà et al., 2019) will be required in the near future.

Beach profiles in the Tordera Delta shoreline typically show a seasonal pattern of erosion and accretion. Typically, beaches in this region show greater width and a flat profile in summer, with reduced width and a steep profile in winter (Marcomini et al., 2007). As the minimum beach width needed to maintain its protective function was calculated to be $26 \mathrm{~m}$ (Valdemoro and Jimenez, 2006), we concluded that $26 \mathrm{~m}$ should be the minimum desired width in winter conditions. The increase in beach width, combined with seasonal patterns of morphology that are similar to that of natural beaches in the region, constitutes a strong signal of stabilization. Although many governmental offices still consider that in urban environments beaches should only prioritise its public us during the bathing season, from this work, we conclude that management of S'Abanell Beach should aim to maintain beach width at a minimum of 26 $\mathrm{m}$ in winter conditions. By June 2018, the width of the northernmost part of the beach was the largest seen this century, excluding the months immediately following nourishment practices before the beach reached its equilibrium state.

Beach width typically increases during periods of high river discharge (Fig. 6). Sedimentary river inputs are the main sediment source for the beach but the opening or closing of the river mouth can affect how the sediments are redistributed along the shorelines. Our findings suggest that, in order to restore a natural sedimentary balance to $S^{\prime} A$ banell, attention needs to be focused on maintaining river flows and enhancing the delivery of riverine sediment to the shoreface.

Public engagement and participation in coastal management has been highlighted as an essential component of Integrated Coastal Zone Management (ICZM) activities (Ernoul, 2010; Lozoya et al., 2011; Areizaga et al., 2012). As such, integrated solutions within ecosystem-based management principles were recommended as the best option following Sardá et al. (2014; 2015). A governance structure ("Taula de la Tordera") was promoted as a tool to facilitate dialogue and co-existence between actors. The environmental overview and assessment report requested by the "Taula de la Tordera" allowed us to analyse the ecological processes that need to be restored if we want to have resilient beaches along the shoreline, ecological flow of the river and sufficient groundwater recharge.

Many of the harmful activities inflicted over the last sixty years on the Tordera Delta region have ceased as a consequence of better knowledge about negative long-term impacts (Sagristà et al., 2019; Sardá et al., in press). The abandonment of these activities has influenced the potential to move towards other types of management solutions, adopting a long-term thinking approach intended to restore the sedimentary balance and to provide space for coastal processes. 


\section{CONCLUSION}

407 During the last decade, the beach of S'Abanell has shown a trend for improvement in its physical conditions as a direct consequence of the artificial beach nourishment actions and the abandonment of previous human-based pressures. Improvements were evident in the northern and central parts of the beach but not in the southern part, near the mouth, where the situation is still critical. Our time series analysis also served to identify areas where the modification of essential processes is compromising beach resilience. The ecological flows of the river, the opening of the river mouth and the situation of the aquifers, are critical to improving the erosion/accretion balance at S'Abanell. In order to recover delta functionality in the future, the region has created a governance structure ("Taula de la Tordera") to facilitate implementation of an ecosystem-based management process, using its basic principles to redress the problems caused by past fragmented coastal management frameworks. Finally, our study demonstrates that under certain conditions on a local scale, artificial nourishment can contribute to restore beach health on a decadal scale.

\section{ACKNOWLEDGMENTS}

We want to express our gratitude to the reviewers of this paper, ilts comments and suggested changes improved largely our manuscript. This work was carried out within the framework of the PLAYA+ (CGL2013-49061) and the ECOPLAYA (RTI2018-095677-B-I00) projects of the National Research Plan of Spain in R+D+i.

\section{REFERENCES}

Areizaga, J., Sanò, M., Medina, R., Juanes, J. (2012). Improving public engagement in ICZM: A practical approach. Journal of Environmental Management, 109: 123-135. https://doi.org/10.1016/j.jenvman.2012.05.006

Ariza, E., Jimenez, J. A., \& sarda, R. (2008a). Seasonal evolution of beach waste and litter during the bathing season on the Catalan coast. Waste Management, 28(12), 2604-2613. http://doi.org/10.1016/J.WASMAN.2007.11.012

Ariza, E., Jiménez, J. A., \& Sardá, R. (2008b). A critical assessment of beach management on the Catalan coast. Ocean \& Coastal Management, 51(2), 141-160. http://doi.org/10.1016/J.OCECOAMAN.2007.02.009

Ariza, E., Sardá, R., Jiménez, J. A., Mora, J., \& Ávila, C. (2007). Beyond Performance Assessment Measurements for Beach Management: Application to Spanish Mediterranean Beaches. Coastal Management, 36(1), 47-66. http://doi.org/10.1080/08920750701682023

Ariza, E., Jimenez, J. A., Sarda, R., Villares, M., Pinto, J., Fraguell, R., Fluvia, M. (2010). Proposal for an integral quality index for urban and urbanized beaches. Environmental Management, 45(5), 998-1013. http://doi.org/10.1007/s00267-010-9472-8

Centre Internacional d'Investigació dels Recursos Costaners (CIIRC). (2010). Estat de la Zona Costanera a Catalunya. Departament Política Territorial i Obres Públiques. Barcelona.

Cormier, C., Kannen, A., Davis, I., Sardá, R. \& Diedrich, A. (2010). Policy fragmentation implications in ecosystembased management in practice. Working Paper. Proceedings of the ICES Annual Science Conference, ICES Annual Science Conference, Nantes, France.

Durán, R., Guillén, J., Ruiz, A., Jiménez, J. A., \& Sagristà, E. (2016). Morphological changes, beach inundation and overwash caused by an extreme storm on a low-lying embayed beach bounded by a dune system (NW Mediterranean). Geomorphology, 274, 129-142. http://doi.org/10.1016/j.geomorph.2016.09.012 
El Mrini, A., Anthony, E. J., Maanan, M., Taaouati, M., \& Nachite, D. (2012). Beach-dune degradation in a Mediterranean context of strong development pressures, and the missing integrated management perspective. Ocean \& coastal management, 69, 299-306. https://doi.org/10.1016/j.ocecoaman.2012.08.004

Ericson, J. P., Vörösmarty, C. J., Dingman, S. L., Ward, L. G., \& Meybeck, M. (2006). Effective sea-level rise and deltas: Causes of change and human dimension implications. Global and Planetary Change, 50(1-2), 63-82. https://doi.org/10.1016/j.gloplacha.2005.07.004

Ernoul, L. 2010, Combining process and output indicators to evaluate participation and sustainability in integrated coastal zone management projects. Ocean and Coast. Management, 53: 711-716. https://doi.org/10.1016/j.ocecoaman.2010.10.001

de Farias, E. G., Lorenzzetti, J. A., \& Chapron, B. (2012). Swell and wind-sea distributions over the mid-latitude and Tropical North Atlantic for the period 2002-2008. International Journal of Oceanography, 2012. https://doi.org/10.1155/2012/306723

Jiménez, J.A., Sardá, R., Serra, J., Pintó, J. \& Guillén, J. (2007). Informe sobre la problemática actual de la playa de $\mathrm{S}$ 'Abanell. Asociación Hostelería de Blanes, 9pp.

Jiménez, J. A., Valdemoro, H. I., Bosom, E., Sánchez-Arcilla, A., \& Nicholls, R. J. (2016). Impacts of sea-level rise-induced erosion on the Catalan coast. Regional Environmental Change, 17(2), 593-603. https://doi.org/10.1007/s10113-016-1052-x

Larson, M., \& Kraus, N. (1989). SBEACH: numerical model for simulating storm-induced beach change. Report 1. Empirical foundation and model development. Tech Report CERC-89-, 9 (US Army Corps of Engineers, Vicksburg).

Lozoya, J. P., Sardá, R., \& Jiménez, J. A. (2011). A methodological framework for multi-hazard risk assessment in beaches. Environmental Science and Policy, 14(6), 685-696. http://doi.org/10.1016/i.envsci.2011.05.002

Marcos, M., Tsimplis, M.N. (2008). Coastal sea level trends in Southern Europe. Geophys J Int 175:70-82. doi:10.1111/j.1365-246X. 2008.03892.x

Marcomini, S., López, R., \& Spinoglio, A. (2007). Uso de la morfología costera como geoindicador de susceptibilidad a la erosión en costas cohesivas, Necochea, Buenos Aires. Rev Asoc Geol Argent.

Mendoza, E. T., \& Jiménez, J. A. (2008). Clasificación de tormentas costeras para el litoral catalán (Mediterráneo NO). Tecnología y Ciencies del Agua, 23(2), 21-32.

Nicholls, R.J., Wong, P.P., Burkett, V., Codignotto, J., Hay, J., McLean, R., Ragoonaden, S. \& Woodroffe. C.D. (2007). Coastal systems and low-lying areas. In: Parry ML, Canziani OF, Palutikof JP, van der Linden P, Hanson CE (Eds). Climate Change 2007: impacts, adaptation and vulnerability. Contribution of Working Group II to the Fourth Assessment Report of the Intergovermental Panel on Climate Change. Cambridge, Cambridge University Press, pp 315-357

Pintó, J., Martí, C., \& Fraguell, R. M. (2014). Assessing current conditions of coastal dune systems of Mediterranean developed shores. Journal of Coastal Research, 30(4), 832-842. https://doi.org/10.2112/JCOASTRES-D-1300116.1

Puertos del Estado. (2016). Conjunto de datos SIMAR-44. Proyecto HIPOCAS, Ministerio de Fomento, (Gobierno de España).

Rovira, A., Batalla, R. J., \& Sala, M. (2004). Balance sedimentario en el tramo bajo de un río Mediterráneo (La Tordera, Cordilleras Costeras Catalanas). Revista de Cuaternario y Geomorfología, 18, 51-56.

Rovira, A., Batalla, R. J., \& Sala, M. (2005). Fluvial sediment budget of a Mediterranean river: the lower Tordera (Catalan Coastal Ranges, NE Spain). Catena, 60(1), 19-42. https://doi.org/10.1016/j.catena.2004.11.001

Sagristà, E., R. Sardá, \& J. Serra. 2019. Consecuencias a Largo Plazo de la Gestión Desintegrada en Zonas Costeras: el Caso del Delta de la Tordera (Cataluña, España). Revista Costas, 1(1): 1-22. https://doi.org/ 10.26359/costas.0101 
Sardá, R. \& Fluvià, M. (1999). Tourist development in the Costa Brava (Girona, Spain): a quantification of pressures on the Coastal Environment. In: Salomons W, Turner K, Lacerda L, Ramachandran S. (Eds.). Perspectives on Integrated Coastal Zone Management. Springer Publ., Berlin, pp: 257-276.

Sardà, R., O'Higgins, T., Cormier, R., Diedrich, A., \& Tintoré, J. (2014). A proposed ecosystem-based management system for marine waters: linking the theory of environmental policy to the practice of environmental management. Ecology and Society, 19(4), art51. https://doi.org/10.5751/ES-07055-190451

Sardá, R., Valls, J. F., Pintó, J., Ariza, E., Lozoya, J. P., Fraguell, R. M., ... Jimenez, J. A. (2015). Towards a new Integrated Beach Management System: The Ecosystem-Based Management System for Beaches. Ocean \& Coastal Management, 118, 167-177. http://doi.org/10.1016/J.OCECOAMAN.2015.07.020

Sardá, R., Sagristà, E. \& Broekman, A. (in press). Towards a new integrated ecosystem-based model for beach management: the case of S'Abanell Beach (North-western Mediterranean. In: Gonçalves, S.C. \& Ferreira, S.C.M. (Eds). Sandy beaches as endangered ecosystems: environmental problems and possible assessment and management solutions. CRC Press/ Taylor \& Francis Group.

Serra, I., \& Pinto, J. (2005). La transformació del paisatge del delta de la Tordera en els darrers cent cinquanta anys. Una anàlisi per mitjà dels canvis en els usos i les cobertes del sòl. Documents d'Anàlisi Geogràfica, 0(46), 81102.

Speybroeck, J., Bonte, D., Courtens, W., Gheskiere, T., Grootaert, P., Maelfait, J. P., ... \& Lancker, V. V. (2006). Beach nourishment: an ecologically sound coastal defence alternative? A review. Aquatic Conservation: Marine and Freshwater Ecosystems, 16(4), 419-435. https://doi.org/10.1002/aqc.733

Suárez de Vivero, J. L., \& Rodríguez Mateos, J. C. (2005). Coastal Crisis: The Failure of Coastal Management in the Spanish Mediterranean Region. Coastal Management, 33(2), 197-214. http://doi.org/10.1080/08920750590917602

Schwartz, M. L. (1967). The Bruun Theory of Sea-Level Rise as a Cause of Shore Erosion. The Journal of Geology, 75(1), 76-92. https://doi.org/10.1086/627232

TW Group. (1988). The WAM Model-A Third Generation Ocean Wave Prediction Model. Journal of Physical Oceanography, 18(12), 1775-1810. http://doi.org/10.1175/1520-0485(1988)018<1775:TWMTGO>2.0.CO;2

UNESCO-IRTCES (2001). Sediment Issues \& Sediment Management in Large River Basins Interim Case Study Synthesis Report. International Sediment Initiative. Technical Documents in Hydrology. UNESCO Office in Beijing \& IRTCES 2011.

Valiela, I., 2006: Global Coastal Change. Blackwell, Oxford, 368 pp

Vila, I., \& Serra, J. (2015). Tordera River Delta system build up (NE Iberian Peninsula): sedimentary sequences and offshore correlation. Scientia Marina, 79(3), 305-317. https://doi.org/10.3989/scimar.04188.07A

Valdemoro, H. I., \& Jiménez, J. A. (2006). The Influence of Shoreline Dynamics on the Use and Exploitation of Mediterranean Tourist Beaches. Coastal Management, 34(4), 405-423. http://doi.org/10.1080/08920750600860324 


\section{FIGURE AND TABLE LEGENDS}

\section{$530 \quad$ Figures}

531 Figure 1: Shoreline regression (shoreline coloured red) and accretion (shoreline coloured blue) of beach area in the

532 Tordera Delta region from 1956 to 2006.

533

Figure 2: A) 3D simulation of the camera's vision of s'Abanell Beach from the elevated point of "Muntanya de Sant Joan" (Image source: Google Earth); B) Photograph from "Muntanya de Sant Joan" showing the 6 transects spatially distributed across the beach; C) Measure taken (cross-hatched area in the picture) in the area of former transect 6.

Figure 3: Weekly evolution of the five transects in the northern-central part of S'Abanell Beach; graphs display information about their protective function (blue; good status, orange; pre-alert status, red; alert status and, black; critical status). Below transects, other categories of information: a) time series of significant wave height with information about wave direction (black for east swell and grey for south-west swell), b) time series of daily rainfall with information about annual precipitation (dark blue=above mean; turquoise=around mean; brown=below mean) and, c) time series of rainfall typology (blue/dark blue lines).

Figure 4: Upper graph: Beach area evolution in the southernmost part of S'Abanell Beach. Lower graph: Distance between the end of the powerhouse and the shoreline. Yellow bars show the monthly average and red points their annual average.

Figure 5: Evolution of the IPP Index. Upper graph: Annual average IPP index for the six analysed transects. Below graph: IPP value for the entire beach (black) vs IPP value for the northern-central part omitting transect 6 (Transects 1 to 5, white colour). In August 2009, 250,000 m3 were deposited on its northern part (T1 transect) as part of the beach nourishment practices.

Figure 6: Twelve months-correlation between beach width, wave direction and sand bar breaching of the Tordera's mouth. Upper graph: time series of swell dynamics (brown for east swell and grey for south-west swell). Middle graph: time series of beach width with growing periods (blue areas). Lower graph: time series of the sand bar breaching in the mouth of the Tordera River (green for openings and grey for closures) representing with the number $(1,2$ or 3$)$ the floods of the river and its relative intensity. 


\section{Editor's and reviewers' comments:}

Lines 54-59 - This long sentence with two semicolons needs to be broken into two separate sentences. Our handling editor suggests the following replacement: "Present sea-level trends in the Mediterranean basin have been estimated by Marcos and Tsimplis (2008) by analyzing available tide-gauge records longer than 35 years between 1.2 and $1.5 \mathrm{~mm}$ yr-1; the same authors estimated in $1.7 \mathrm{~mm}$ yr-1 a sea-level 13-year long time series in the Barcelona Harbor. Based on these estimates, we can assume that the average rate sea level rise in the region is around $1.5 \mathrm{~mm}$ per year, corresponding to a retreat of approximately $15-20 \mathrm{~cm}$ of the beach strands along the coast (Schwartz's Bruun rule; Schwartz, 1967). DONE

Lines 60-61 - The word "only" allows no room for other drivers and the addition of the word "then" creates a grammatical error in this revised sentence. Our Handling Editor suggests the following replacement: "The remaining $80 \mathrm{~cm}$ per year can be explained, in part or perhaps completely, by human interference with natural depositional processes due to changes in runoff and sediment delivery to the coast." DONE

Line 125 - There a problem with subject-verb agreement in this revised line: "the aquifer level abruptly diminish and it is depleted." Our Handling Editor suggests the following: "the aquifer level is abruptly diminished as groundwater depletion exceeds the rate of recharge." DONE

Line 147 - The words "both" and "its" should be deleted in this phrase: "both the wells and its power house were disconnected". There are more than 2 wells. And "both" is not required in the sentence. DONE

Line 159 - The word "records" should be changed to "record" in this phrase: "the first year of records (2009)." DONE

Line 180 - please change "bigger than $30 \mathrm{~m}$ " to "greater than $30 \mathrm{~m}$ ". DONE

Line 237 - The period after the end parenthesis mark after the word "swell)." should be deleted. DONE

Lines 235-237 - This paragraph contains references to colors (green, blue, brown and white) referring to a "display" that is not included in the manuscript. The following revision to the text would provide context needed for text about colors that are mentioned: delete "In this case" and replace with "In the graphic design display for managers, " DONE 
Line 239 Page 6, line 242-244 - The authors have broken a long sentence into two, but in the process they created new syntax problems and grammatical errors with these two new sentences: "Following the degraded condition tendency, stakeholder demands to improve delta environmental conditions and to deal with erosive human factors affecting its beaches were observed. We recommended coastal managers to move towards a more integrated, ecosystem-based approach for beach management." Our Handling editor suggests the following replacement, which is based on the findings in the manuscript: "Over the past two decades natural resource managers and other stakeholders in the Tordera Delta region have become increasingly concerned about the trends and impacts of erosion along S'Abanell Beach. We have recommended a move towards a more integrated, ecosystem-based approach for beach management that focuses on restoring deltaic processes, understanding the influence of seasonal maritime conditions and aquifer recharge, and actions that enhance sediment delivery and retention along the coastline." DONE

Line 301 - Please delete the unnecessary comma after (2013-2014). DONE

Lines 321-322 - The following sentence is confusing and awkward in English: "In spite of not having another episode of $\mathrm{C} 1$ flood during the studied period, our analysis served to see that for C2 and C3 floods the beach response is more delayed." Analyses don't "serve to see". Our handling editor recommends that the sentence be deleted entirely because the subsequent text and graphics explain the beach response to C1, C2 and C3 floods. DONE

Line 334 - please delete the unnecessary comma after "S'Abanell Beach". DONE

Line 404 - please delete the unnecessary comma after the word "conditions". DONE

Please note that in the Abstract and throughout the manuscript, the words "river" and "delta" should begin with a capital letter when those words immediately follow "Tordera", as in Tordera River and Tordera Delta as proper names of geographic features. Likewise, "S'Abanell beach" should be changed to "S'Abannel Beach" throughout the manuscript. DONE

The note at the bottom of figure 5 "During 2009 beach regenerations were done on this area" is a problem because the manuscript refers to "beach nourishment" not beach regeneration. The word "regeneration" does not appear anywhere in the manuscript. And what "area" does the phrase refer to? All 6 transects are included in the figure. Our Handling Editor suggests that the line at the bottom of Figure 5 be removed. If the authors wish to add a note about beach nourishment, they could add it to the caption for Figure 5. If they add it to the caption, they should include the month and date of the beach nourishment project(s). DONE 


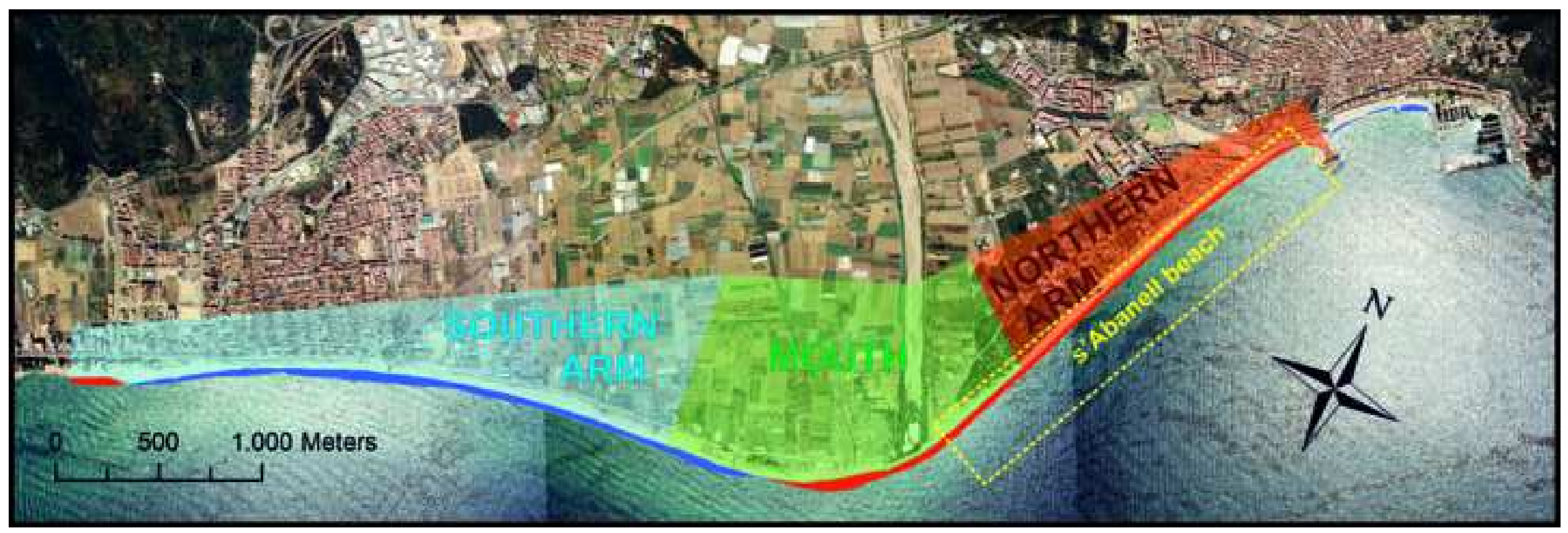




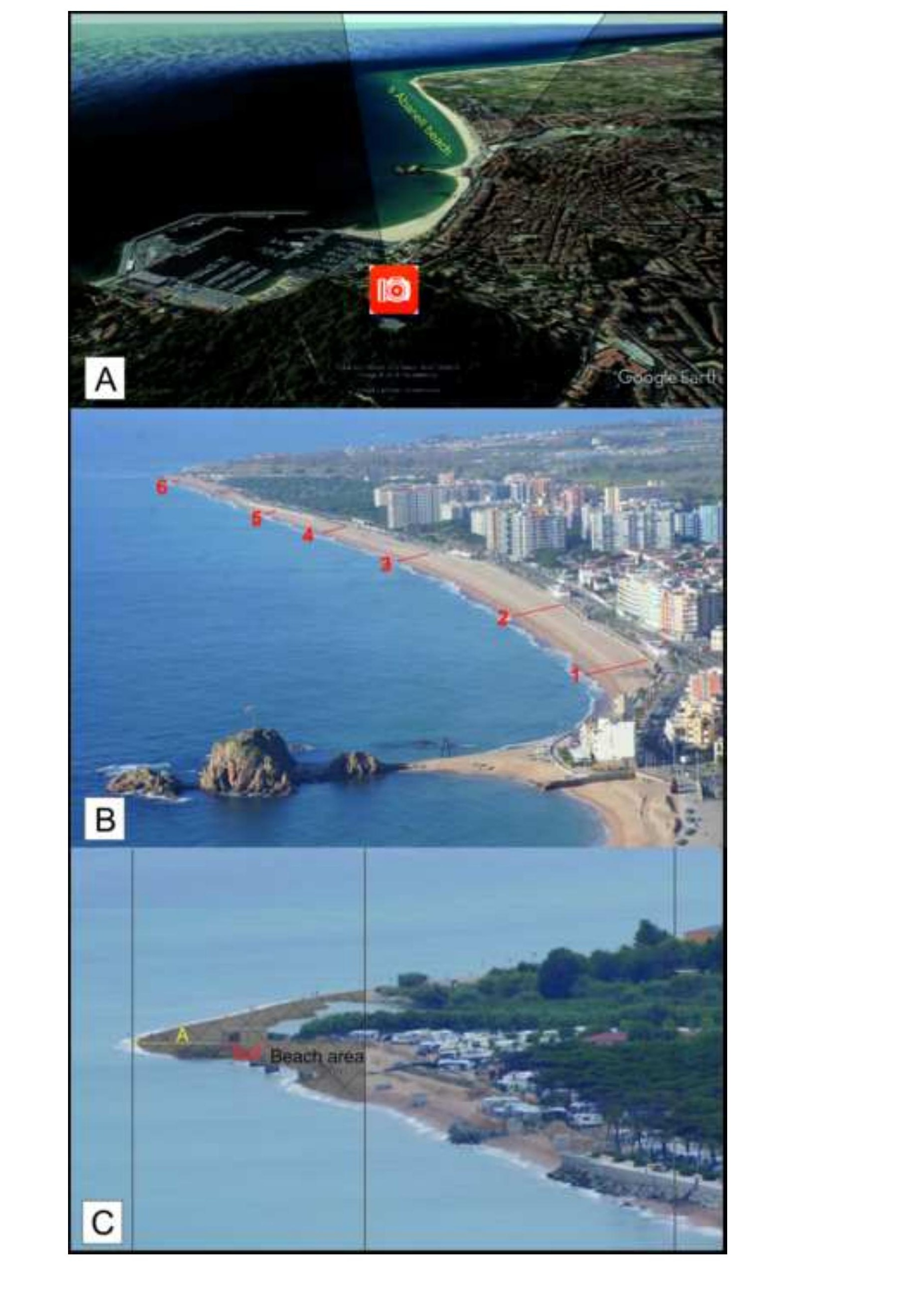

.

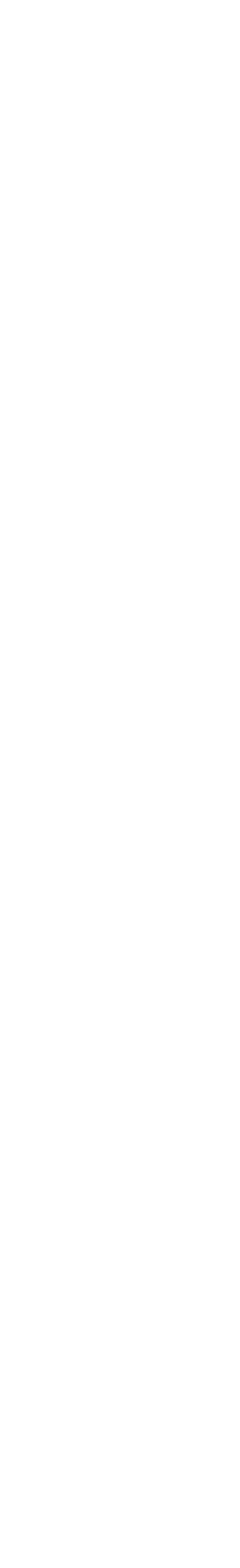




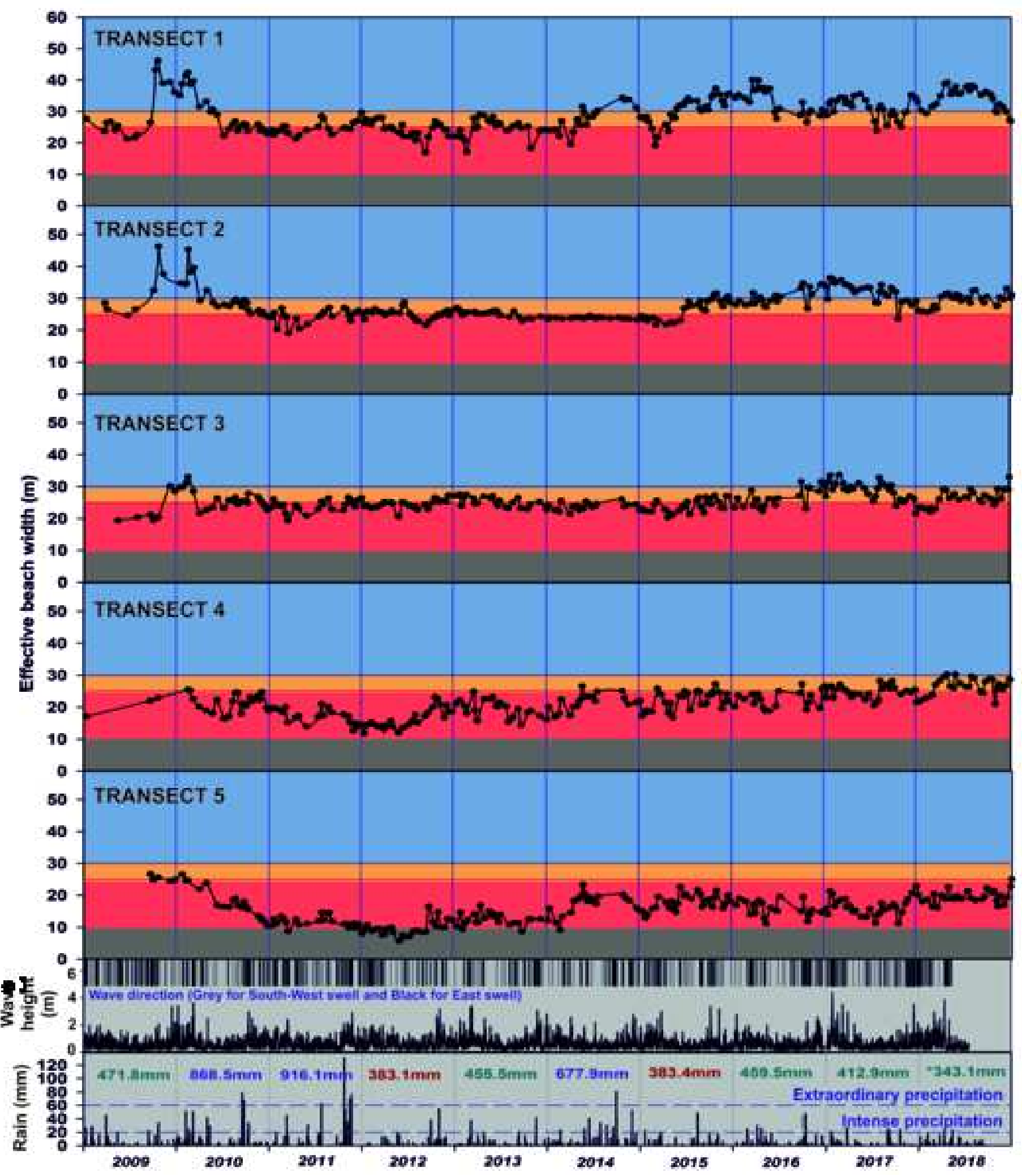



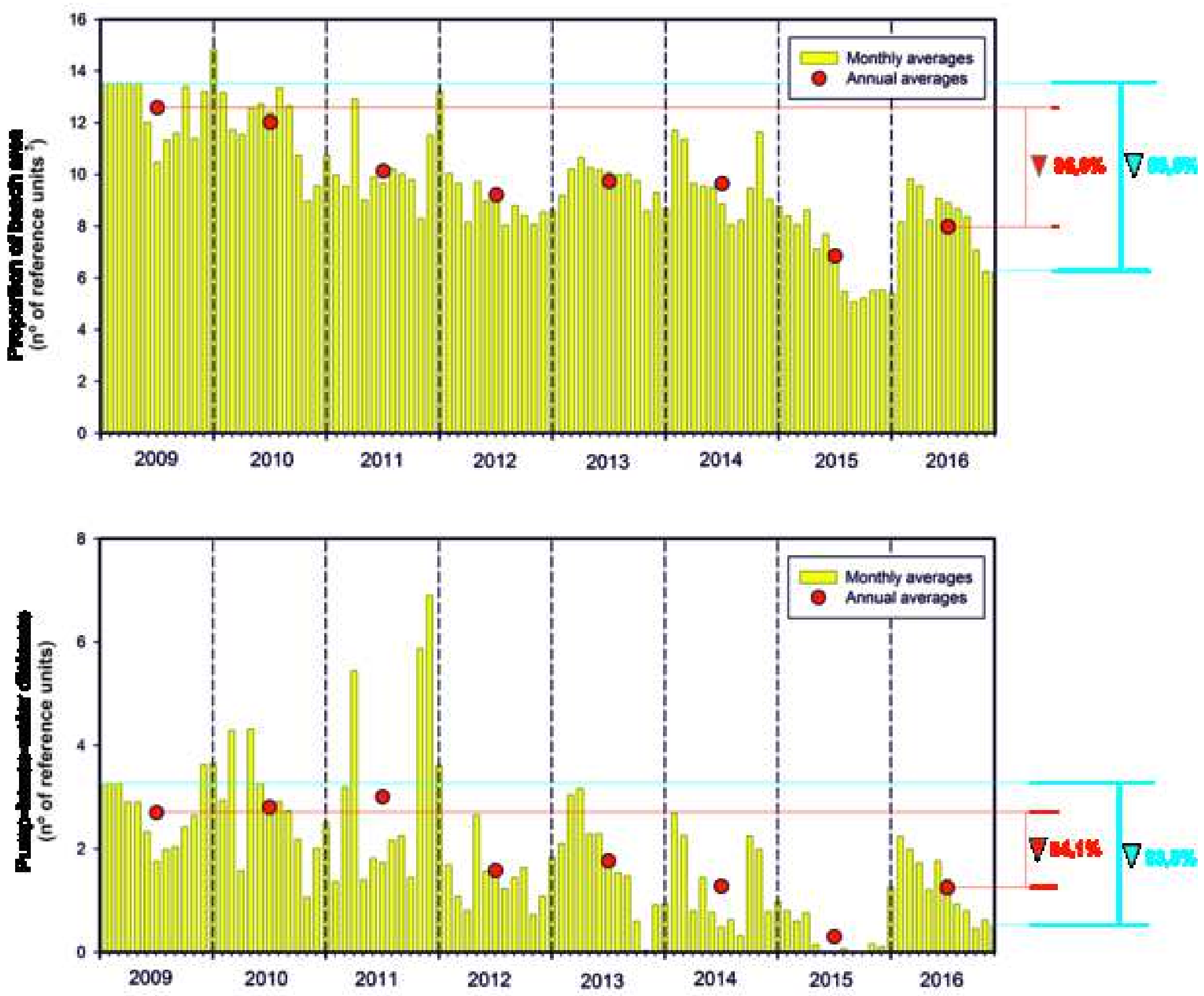


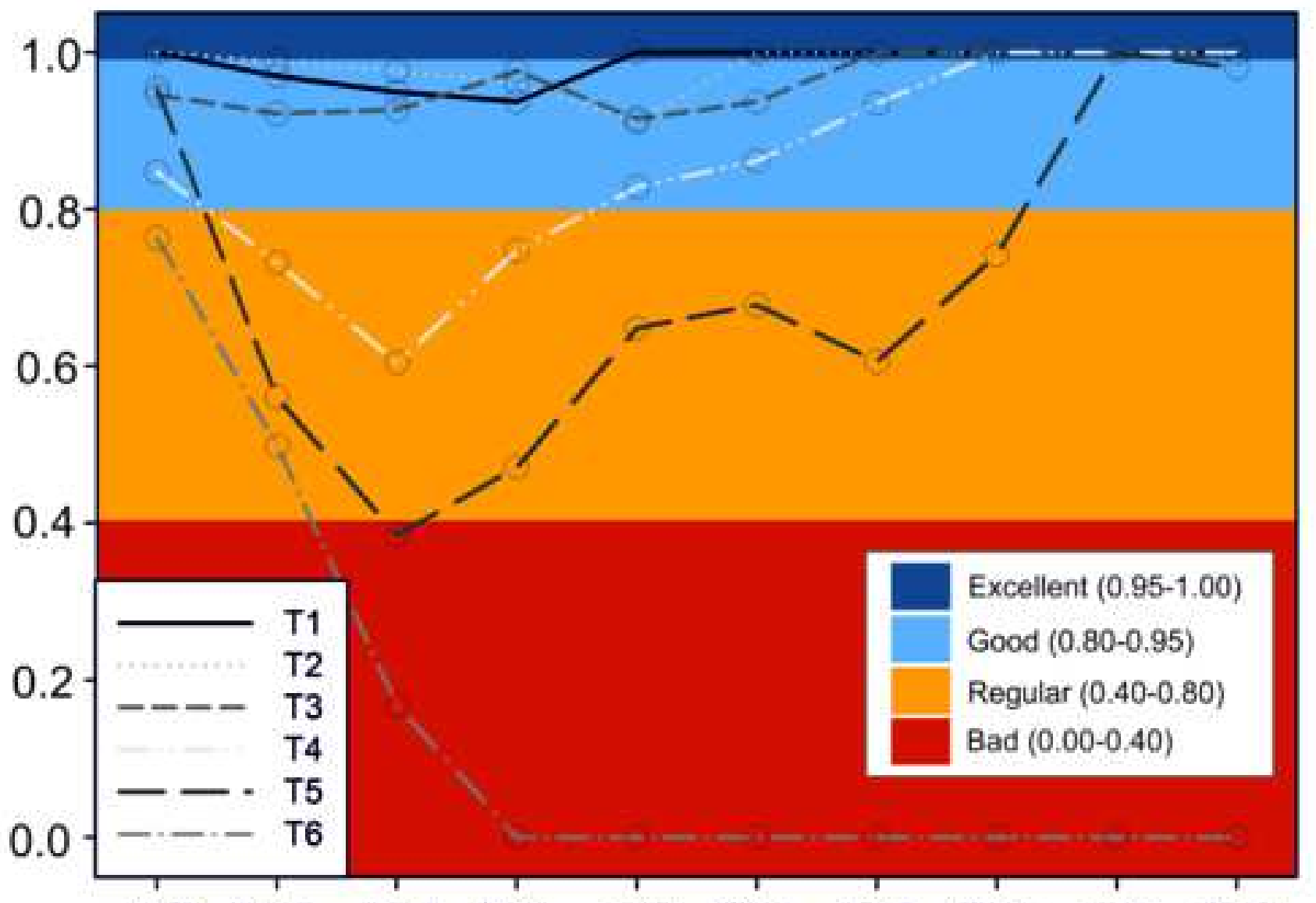

\begin{tabular}{c|cccccccccc}
\hline Pannual & 2009 & 2010 & 2011 & 2012 & 2013 & 2014 & 2015 & 2016 & 2017 & 2018 \\
\hline \begin{tabular}{l} 
abrage \\
\hline
\end{tabular} & 0.92 & 0.78 & 0.67 & 0.68 & 0.72 & 0.75 & 0.76 & 0.79 & 0.83 & 0.83
\end{tabular}

1. Thensects)

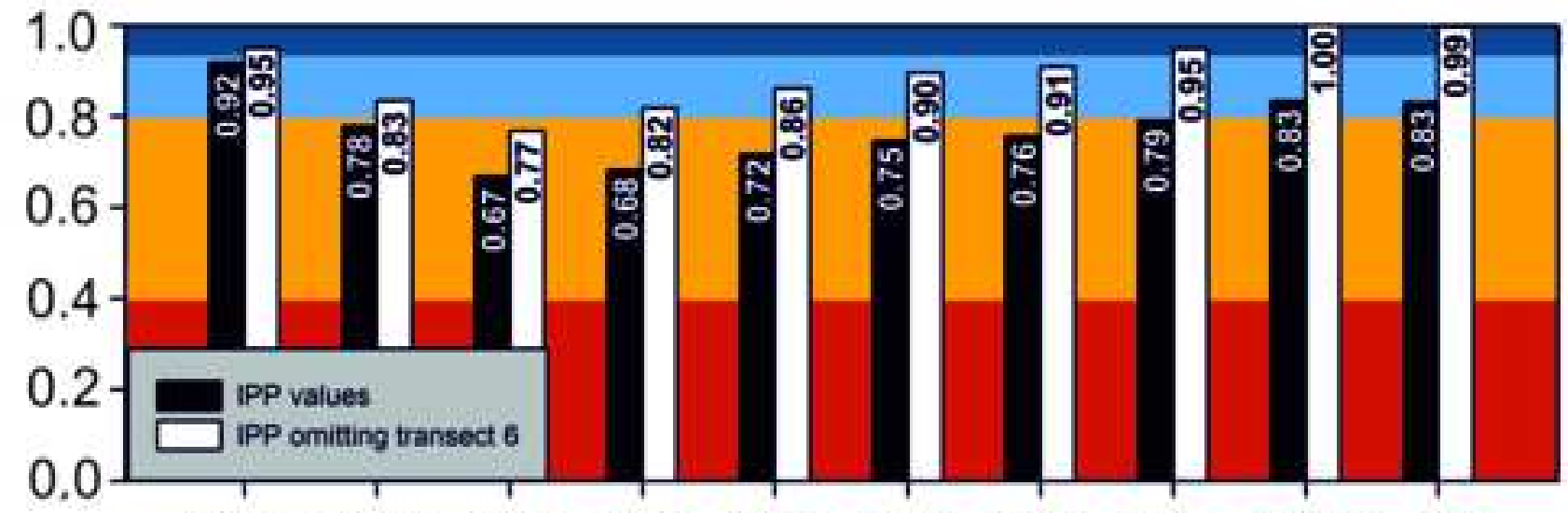
EP annual iverage (owitting T6)

$\begin{array}{llllllllll}2009 & 2010 & 2011 & 2012 & 2013 & 2014 & 2015 & 2016 & 2017 & 2018\end{array}$

\begin{tabular}{l|llllll|lll|}
0.95 & 0.83 & 0.77 & 0.82 & 0.86 & 0.90 & 0.90 & 0.95 & 1.00 & 0.99 \\
\hline
\end{tabular}




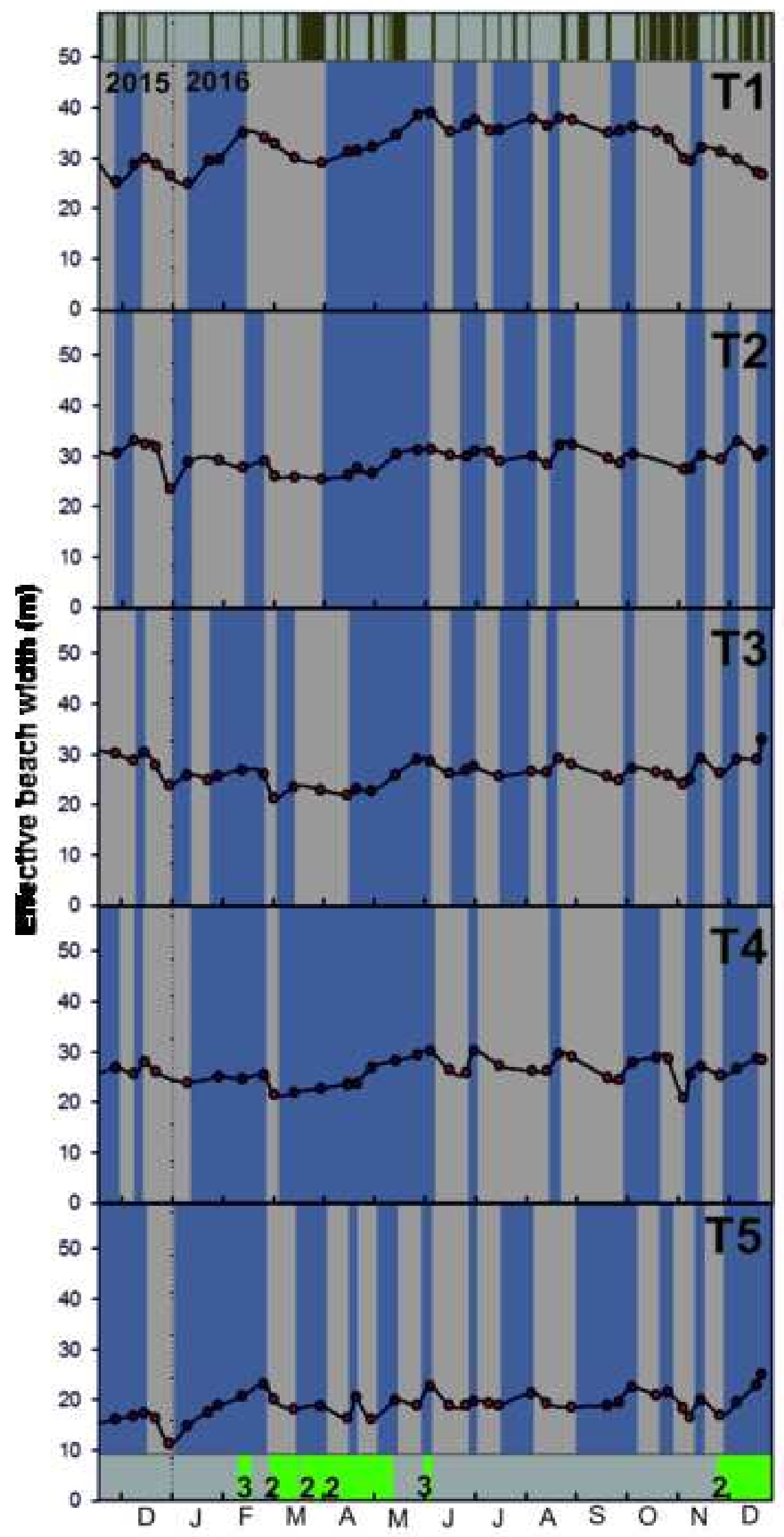

